\title{
Pengaruh Penambahan SPACE terhadap Karakteristik dan Stabilitas Gel Freeze Dried Amniotic Membrane Stem Cell-Metabolite Product
}

\author{
Ria Hanistya ${ }^{1}$, Tristiana Erawati ${ }^{1}$, Cita Rosita Sigit Prakoeswa ${ }^{2,3}$, Fedik Abdul Rantam $^{4,5}$, Widji Soeratri ${ }^{{ }^{*}}$ \\ ${ }^{1}$ Departemen Farmasetika, Fakultas Farmasi, Universitas Airlangga, Surabaya, Indonesia \\ ${ }^{2}$ Departemen Ilmu Kesehatan Kulit dan Kelamin, RSUD Dr. Soetomo, Surabaya, Indonesia \\ ${ }^{3}$ Departemen Dermatologi, Fakultas Kedokteran, Universitas Airlangga, Surabaya, Indonesia \\ ${ }^{4}$ Pusat Penelitian dan Pengembangan Stem Cell, Universitas Airlangga, Surabaya, Indonesia \\ ${ }^{5}$ Laboratorium Virologi dan Imunologi, Departemen Mikrobiologi, Fakultas Kedokteran Hewan, Universitas Airlangga, \\ Surabaya, Indonesia
}

*Corresponding author: widjisoeratri@yahoo.com

Submitted: 17 Januari 2020

Accepted: 31 Januari 2020

Published: 30 November 2020

\begin{abstract}
Background: Skin, the largest organ in human body is an important site for delivering drug or active ingredients. Some active ingredients are macromolecule with molecule size more than 500 Da hence delivering it into stratum corneum become more challenging and need penetration enhancer to traverse the stratum corneum. SPACE (Skin Penetrating and Cell Entering) are sequences of small molecule of peptide which have demonstrated their potential as enhancer in delivering macromolecule in non invasive way. SPACE is nouvelle enhancer and the study about their effects on physical characteristic and stability in topical gel formulation are limited. Objective: This research was conducted to examine the effect of SPACE toward physical characteristic and stability of Amniotic Membrane Stem Cell-Metabolite Product gel. Methods: Gel physical characteristics were measured by evaluating gel physical appearance, $\mathrm{pH}$ and spreading diameter measurement. The physical stability test was evaluated by observing organoleptic parameter, $\mathrm{pH}$ and spreading diameter measurement during 30 days of storage. Results: The result of physical stability test showed that the observed gel have transparent appearance, thick consistency and smooth texture with $\mathrm{pH}$ around 6.1 and spreading diameter 6.0 cm. Freeze dried AMSC-MP gel was stable during 30 days of storage. Conclusion: The addition of SPACE to gel formulation did not disturb the gel physical characteristic and stability.
\end{abstract}

Keywords: amniotic membrane stem cell-metabolite product, SPACE-peptide, gel, characteristic, stability

\begin{abstract}
Abstrak
Pendahuluan: Sebagai organ terluas yang menyusun tubuh manusia, kulit menjadi salah satu lokasi penting dalam menghantarkan obat atau bahan aktif tertentu ke dalam tubuh manusia. Beberapa bahan aktif berbentuk makromolekul dengan berat molekul lebih dari 500 Da tidak dapat menembus stratum korneum sehingga membutuhkan bantuan penetration enhancer. SPACE (Skin Penetrating and Cell Entering) merupakan rangkaian molekul peptida berukuran kecil yang berpotensi bekerja sebagai enhancer dalam menghantarkan makromolekul dengan cara yang tidak invasif. Namun SPACE merupakan enhancer golongan baru sehingga efek penambahan SPACE terhadap karakteristik dan stabilitas fisik pada formulasi sediaan gel masih belum banyak diketahui. Tujuan: Penelitian kali ini bertujuan untuk mengevaluasi efek pemberian SPACE pada karakteristik dan stabilitas fisik sediaan gel freeze dried Amniotic Membrane Stem Cell-Metabolite Product. Metode: Karakteristik fisik sediaan gel freeze dried AMSC-MP dengan SPACE dievaluasi menggunakan parameter organoleptis (warna, bau, bentuk, tekstur), $\mathrm{pH}$ dan diameter sebar sediaan. Stabilitas fisik sediaan akan dievaluasi dengan menguji karakteristik fisik sediaan selama 30 hari penyimpanan. Hasil: Gel freeze dried Amniotic Membrane Stem Cell memiliki pH sekitar 6,1 dan diameter sebar sediaan sekitar 6,0 cm. Seluruh hasil pengujian karakteristik masih memenuhi rentang yang dipersyaratkan. Hasil uji karakteristik dianalisis menggunakan
\end{abstract}


statistika metode ANOVA satu arah dan tidak menunjukkan adanya perbedaan bermakna antar formula. Semua formula F1, F2, F3 dan F4 stabil selama 30 hari penyimpanan. Kesimpulan: Penambahan SPACE tidak mempengaruhi karakteristik dan stabilitas fisik sediaan gel freeze dried Amniotic Membrane Stem CellMetabolite Product.

Kata kunci: amniotic membrane stem cell-metabolite product, SPACE-peptide, gel, karakteristik, stabilitas

\section{PENDAHULUAN}

Sebagai organ terluas yang menyusun tubuh manusia, kulit menjadi salah satu lokasi penting dalam menghantarkan obat atau bahan aktif tertentu ke dalam tubuh manusia agar dapat memberikan efek farmakologis. Penghantaran bahan aktif melalui kulit mendapatkan perhatian yang besar dari para peneliti dari tahun ke tahun karena bersifat non invasif, mudah dilakukan dan memberikan banyak keuntungan bagi penggunanya. Hanya saja penghantaran melalui kulit memiliki kesulitan sendiri karena kulit memiliki hambatan protektif terhadap masuknya bahan aktif dari lingkungan sekitarnya. Lapisan stratum korneum menyusun lapisan kulit bagian luar dan terdiri dari keratin tertanam dalam lipid kristalin interselular dan bersifat impermeable terhadap bahan aktif yang memiliki berat molekul lebih dari $500 \mathrm{Da}$.

Amniotic membrane stem cells (AMSC) sebagai salah satu alternatif bahan aktif yang dapat digunakan memiliki potensi yang besar penggunaanya untuk diaplikasikan secara klinis (Insausti dkk., 2014; Miki, 2011). Rosita dkk. (2018) mengkondisikan sebuah medium untuk AMSC dimana medium tersebut terdapat metabolite product yang mengandung growth factors seperti TGF- $\beta$ yang memicu protein yang dapat mencerahkan kulit, hepatocyte growth factors, dan insulin growth factors yang memicu pembentukan protein yang berfungsi untuk mencegah kerutan pada kulit. Sitokin dan growth factors di dalam Amniotic Membrane Stem Cells-Metabolite Product (AMSCMP) memiliki karakteristik berupa makromolekul hidrofilik yang memiliki ukuran molekul lebih dari 15000 Da sehingga tidak dapat menembus lapisan stratum korneum untuk dapat memberikan efek farmakologisnya. Agar dapat meningkatkan penetrasi suatu bahan aktif di dalam sediaan topikal, maka dibutuhkan adanya penambahan enhancer.

Peptida sebagai enhancer pada mulanya dikenal dengan sebutan Protein Transductions Domain (PTD) atau cell penetrating protein (CPP). PTD merupakan suatu sekuens dari asam amino dengan panjang antara 5 - 30 rangkaian (Borelli dkk., 2018). PTD dirancang untuk menembus membran biologis secara efisien dan memfasilitasi cell uptake dari molekul yang dipasangkan pada PTD. Kemampuan PTD dalam meningkatkan penetrasi molekul menyebabkan peningkatkan penggunaan PTD dalam penelitian pada penghantaran bahan aktif farmasetik maupun kosmetik (Chen dkk., 2013). SPACE (Skin Penetrating and Cell Entering) adalah bagian dari PTD yang berfungsi sebagai enhancer peptida yang berpotensi meningkatkan penetrasi bahan aktif berbentuk makromolekul seperti AMSC-MP ke dalam kulit. Hsu \& Mitragotri (2011) melakukan penelitian pada SPACE dengan sekuens ACTGSQTHHQTH. Penelitian ini menunjukkan bahwa SPACE dapat berpenetrasi dengan baik ke dalam dermis pada kulit babi dan manusia termasuk pada keratinosit, fibroblast dan sel endotelial. Penggunaan SPACE dalam formulasi SiRNA sebagai terapi atopik dermatitis menunjukkan bahwa SPACE dapat melewati stratum korneum menuju membran sel viabel. Analisa dengan FTIR menggunakan kulit manusia menunjukkan bahwa SPACE bekerja dengan cara mengubah susunan keratin pada korneosit dan tidak mempengaruhi susunan lipid pada stratum korneum. Pernyataan ini diperjelas oleh Kumar dkk. (2014) yang menyebutkan bahwa SPACE bekerja tanpa mempengaruhi sifat elektrostatis dari kulit namun secara signifikan mempengaruhi susunan keratin $\alpha$-helix pada stratum korneum. SPACE berikatan dengan keratin dan menstabilkan struktur coiled coil dari keratin di dalam korneosit sehingga menciptakan lebih banyak rute penghantaran secara transelular yang lebih mudah dilalui bagi bahan aktif yang bersifat hidrofilik dibandingkan jika harus melewati susunan lipid di stratum korneum.

Gel merupakan suatu pembawa yang ideal bagi suatu sediaan perawatan kulit karena gel bersifat lebih tidak berminyak dibanding sediaan krim, tidak menimbulkan rasa yang tidak nyaman karena gel memiliki tekstur yang lembut dan tidak lengket (Lund, 1994). Gel membentuk suatu lapisan yang menempel dengan elegan dan baik sehingga melindungi kulit. Kadar air yang tinggi pada gel menimbulkan sensasi yang menyejukkan sehingga meningkatkan kenyamanan penggunanya. Basis gel terdiri dari 
berbagai macam polimer. Polimer yang digemari dalam penggunaannya sebagai basis gel dalam industri farmasi dan kosmetik adalah carbomer (Barry, 1983). Carbomer 940 dipilih karena stabil terhadap suhu selama proses pembuatan dan menghasilkan gel transparan dengan konsistensi yang baik. Pada produk kosmetik, Carbomer 940 digunakan pada rentang konsentrasi 0,5 - 5\% (Rosita dkk., 2010). Penelitian ini bertujuan untuk mengevaluasi pengaruh SPACE terhadap karakteristik dan stabilitas fisik gel freeze dried Amniotic Membrane Stem Cell.

\section{BAHAN DAN METODE}

\section{Bahan}

Seluruh bahan yang digunakan dalam penelitian ini memiliki kemurnian pharmaceutical grade, antara lain AMSC-MP (Instalasi Bank Jaringan dan Sel, RSUD Dr. Soetomo Surabaya), SPACE-Peptide (MedChem, USA) dan basis gel Carbopol 940 (PT Adimitra Prima).

\section{Metode}

Pembuatan sediaan gel

Langkah pertama dalam membuat sediaan gel adalah dengan melarutkan bahan aktif AMSC-MP di dalam aquabidest. Campuran tersebut kemudian dicampur dengan SPACE-Peptide. AMSC-MP yang sudah menyatu dengan SPACE selanjutnya diaduk ke dalam Carbopol 940 yang sudah dikembangkan kemudian dicampur dengan homogenizer Ultra Turrax High Shear Homogenizer pada kecepatan 100 rpm selama 10 menit. Pada pembuatan sedian gel dilakukan replikasi pembuatan sebanyak tiga kali. Rancangan formula pembuatan gel freeze dried AMSC-MP dapat dilihat pada Tabel 1.

\section{Evaluasi karakteristik fisik sediaan gel \\ Pemeriksaan parameter organoleptis}

Evaluasi terhadap parameter organoleptis dilakukan dengan cara mengamati penampilan dari sediaan meliputi warna, bau, tekstur dan konsistensi dari sediaan. Hasil evaluasi terhadap parameter organoleptis sediaan dapat dilihat pada Tabel 2.

Tabel 1. Rancangan formula sediaan gel

\begin{tabular}{lccccc}
\hline \multirow{2}{*}{ Bahan } & \multirow{2}{*}{ Fungsi } & \multicolumn{4}{c}{ Konsentrasi Formula (\%) (b/b) } \\
\cline { 3 - 6 } & Bahan Aktif & 0,008 & 0,008 & 0,008 & 0,008 \\
\hline AMSC-MP & Enhancer & 0 & 0,008 & 0,016 & 0,024 \\
SPACE-Peptide & Enhas & - & - \\
Carbopol 940 & Basis & - & - & & FIII \\
\hline
\end{tabular}

Tabel 2. Hasil pengamatan organoleptis sediaan gel

\begin{tabular}{ccccc}
\hline \multirow{2}{*}{ Formula } & \multicolumn{4}{c}{ Pemeriksaan Organoleptis } \\
\cline { 2 - 5 } & Warna & Bau & Konsistensi & Tekstur \\
\hline F1 & Tidak Berwarna & Berbau amis seperti telur & Kental & Lembut \\
F2 & Tidak Berwarna & Berbau amis seperti telur & Kental & Lembut \\
F3 & Tidak Berwarna & Berbau amis seperti telur & Kental & Lembut \\
F4 & Tidak Berwarna & Berbau amis seperti telur & Kental & Lembut \\
\hline
\end{tabular}

\section{Evaluasi pH sediaan}

$\mathrm{pH}$ sediaan dari tiap formula diperiksa menggunakan alat $\mathrm{pH}$ meter Schotz glass mainz tipe CG-842 yang sudah terkalibrasi. Pemeriksaan pH dilakukan dengan cara mengambil sediaan sebanyak 1 gram kemudian dilarutkan dalam $9 \mathrm{~mL}$ aquademineralisata bebas $\mathrm{CO}_{2}$. Selanjutnya eletroda dimasukkan kemudian dicatat $\mathrm{pH}$ sediaan di layar yang tertera (Ghayah dkk., 2014).

\section{Pengukuran diameter penyebaran sediaan}

Penentuan diameter penyebaran sediaan dilakukan dengan cara meletakkan sediaan gel yang akan diuji sebanyak 1 gram di atas pelat kaca berskala. Kemudian sediaan tersebut ditutup menggunakan pelat kaca yang lain. Pelat kaca yang digunakan berukuran $20 \times 17 \mathrm{~cm}$, tebal $5 \mathrm{~mm}$ dan berat 404,5 gram. Setelah ditutup dengan pelat kaca, kemudian ditambahkan beban di atasnya. Setelah tiga menit, diameter sediaan dicatat. Penambahan beban dilakukan secara bertingkat setiap 10 gram dan dihentikan ketika diameter sediaan konstan (Rosita dkk., 2010).

\section{Evaluasi stabilitas fisik sediaan gel}

Uji stabilitas fisik dilakukan untuk mengetahui ketahanan sistem secara fisika selama disimpan pada suhu ruang. Sampel gel AMSC-MP disimpan pada suhu ruang selama 30 hari pada suhu $30 \pm 0,5$ dan diamati organoleptis, $\mathrm{pH}$ dan diameter sebarnya.

\section{Analisis statistika}


Analisis statistika untuk uji karakteristik fisik dan uji stabilitas fisik selama 30 hari pada kelompok F1 hingga F4 dianalisis dengan menggunakan metode analisis varian (ANOVA) one way. Apabila hasil yang diperoleh $\alpha<0,05$ maka ada perbedaan bermakna antar formula dan dapat dilanjutkan dengan uji post hoc tukey HSD.

\section{HASIL DAN PEMBAHASAN}

Berdasarkan hasil pengamatan pada parameter organoleptis diperoleh sediaan yang transparan dan jernih pada semua formula, konsintensi yang sedikit kental dan memiliki tekstur yang lembut. Dari keseluruhan sediaan gel yang dibuat, semuanya memiliki bau yang spesifik. Hal ini dikarenakan bahan aktif freeze dried AMSC-MP memiliki bau yang amis seperti telur.

Pemeriksaan $\mathrm{pH}$ dilakukan untuk mengetahui apakah penambahan SPACE memberikan pengaruh terhadap $\mathrm{pH}$ sediaan. Penentuan nilai $\mathrm{pH}$ pada sediaan gel freeze dried AMSC-MP dilakukan menggunakan alat $\mathrm{pH}$ meter. $\mathrm{pH}$ sediaan gel freeze dried AMSC-MP di dalam basis yang sudah dikembangkan berada pada rentang $\mathrm{pH}$ antara 5,5 - 5,8. SPACE memiliki $\mathrm{pH}$ antara 7,2 sehingga penambahan SPACE meningkatkan $\mathrm{pH}$ sediaan gel freeze dried AMSC-MP menjadi 6,1. Hasil pengukuran $\mathrm{pH}$ sediaan dapat dilihat pada Gambar 1.

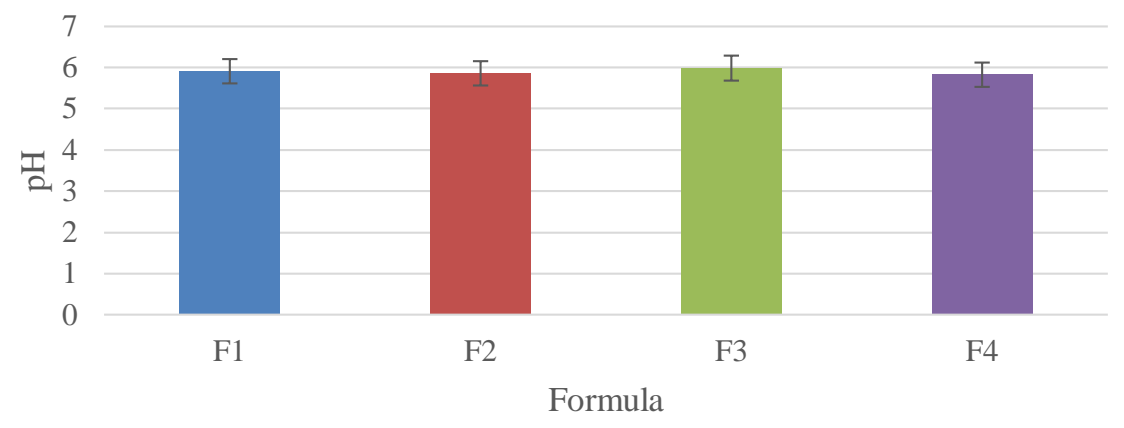

Gambar 1. Histogram hasil pengujian pH sediaan gel

Pengukuran $\mathrm{pH}$ dilakukan untuk mencegah terjadinya iritasi kulit yang disebabkan $\mathrm{pH}$ yang terlalu tinggi atau terlalu rendah. Iritasi yang dapat terjadi karena $\mathrm{pH}$ sediaan terlalu tinggi ataupun terlalu rendah adalah kulit akan menjadi kering, bersisik dan menjadi gatal (Shoviantari, 2017). Sehingga rentang $\mathrm{pH}$ harus dijaga pada rentang yang aman bagi kulit yaitu antara 4 - 6 (Rahmasari, 2018).

Kemampuan diameter sebar sediaan ditentukan dengan cara mengukur diameter penyebaran sediaan. Evaluasi ini dilakukan untuk mengetahui kemudahan sediaan digunakan. Diameter sebar suatu sediaan gel dapat dikatakan baik apabila gel dapat dengan mudah dioleskan pada kulit tanpa penekanan yang kuat dengan jari-jari tangan (Oktaviasari \& Abdul, 2017). Kemudahan suatu sediaan untuk menyebar dihubungkan dengan luasan permukaan kulit tempat dimana sediaan digunakan. Semakin mudah sediaan digunakan, maka sediaan yang kontak dengan kulit akan semakin luas sehingga bahan aktif dalam sediaan dapat terdistribusi secara merata. Pengujian ini dilakukan pada semua formula sehingga perlu digunakan salah satu titik penambahan beban untuk membandingkan luas sebaran masing-masing formula. Persyaratan daya sebar yang baik adalah dengan pertambahan luas 4,0 - 6,0 cm (Oktaviasari \& Abdul, 2017). Dari hasil pengujian didapatkan bahwa kemampuan diameter sebar sediaan gel freeze dried AMSC-MP berkisar antara 5,9 - 6,1 cm (Gambar 2). Kemudahan penyebaran sediaan didapatkan dari nilai slope persamaan regresi hasil profil penyebaran yang diperoleh dengan cara menghubungkan beban dan diameter penyebaran. Semakin besar nilai slope yang diperoleh dapat disimpulkan bahwa sediaan semakin mudah menyebar. Analisis statistika menyatakan bahwa nilai $p$ value (sig.) lebih besar dari 0,05 sehingga tidak ada perbedaan bermakna pada profil penyebaran sediaan F1 sampai F4. 


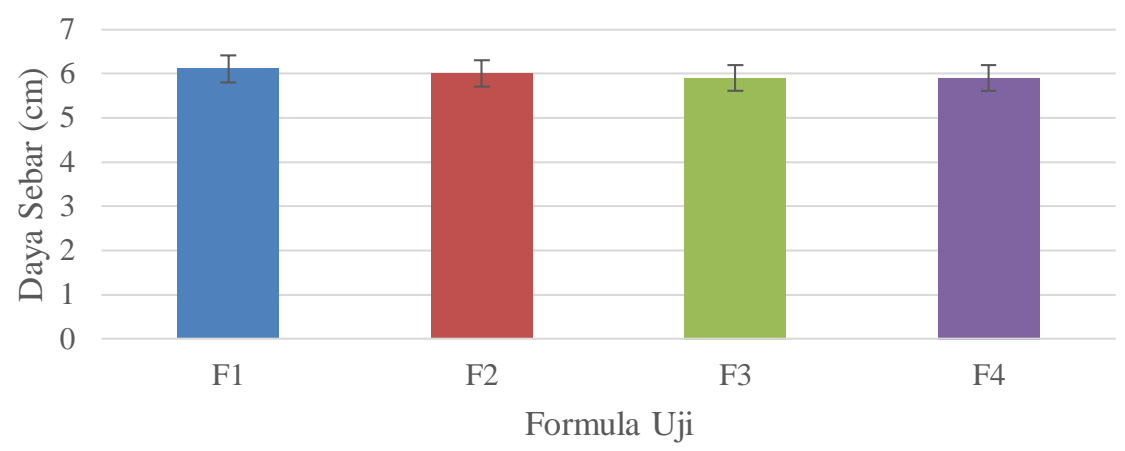

Gambar 2. Histogram hasil pengujian daya sebar sediaan gel pada berat konstan 40 gram

Pada evaluasi terhadap stabilitas fisik sediaan gel, pengamatan organoleptis dilakukan setiap 7 hari sekali dan dbandingkan dengan hari ke 0. Dari hasil pengamatan secara visual didapatkan gel yang tidak berwarna, berbau spesifik dengan konsistensi yang kental dan tekstur yang lembut pada semua formula. Pada akhir penyimpanan (hari ke 30), konsistensi gel pada F3 dan F4 meningkat dibanding F1 dan F2. Peningkatan konsistensi ini terjadi karena gel mengalami syneresis. Syneresis menghilangkan kelembaban pada gel karena ionisasi gugus hidroksil yang berkurang dan terbentuknya ikatan intramolekuler pada hidrogen. Hilangnya kelembaban tersebut akan mengeliminasi ikatan antara pelarut dengan molekul polimer sehingga pelarut akan memisah dan meningkatkan konsistensi dari gel (Rosita dkk., 2010).

Evaluasi terhadap $\mathrm{pH}$ sediaan dilakukan untuk mengetahui pengaruh SPACE terhadap $\mathrm{pH}$ sediaan gel freeze dried AMSC-MP. Berdasarkan hasil statistika Annova pada pengujian stabilitas $\mathrm{pH}$ gel di semua formula didapatkan nilai $p$ value (sig.) lebih besar dari 0,05 yang artinya penambahan konsentrasi SPACEPeptide tidak berpengaruh terhadap $\mathrm{pH}$ sediaan gel freeze dried AMSC-MP dan $\mathrm{pH}$ sediaan stabil selama penyimpanan di suhu ruang selama 30 hari. Histogram hasil evaluasi $\mathrm{pH}$ sediaan gel freeze dried AMSC-MP selama 30 hari penyimpanan dapat dilihat pada Gambar 3.

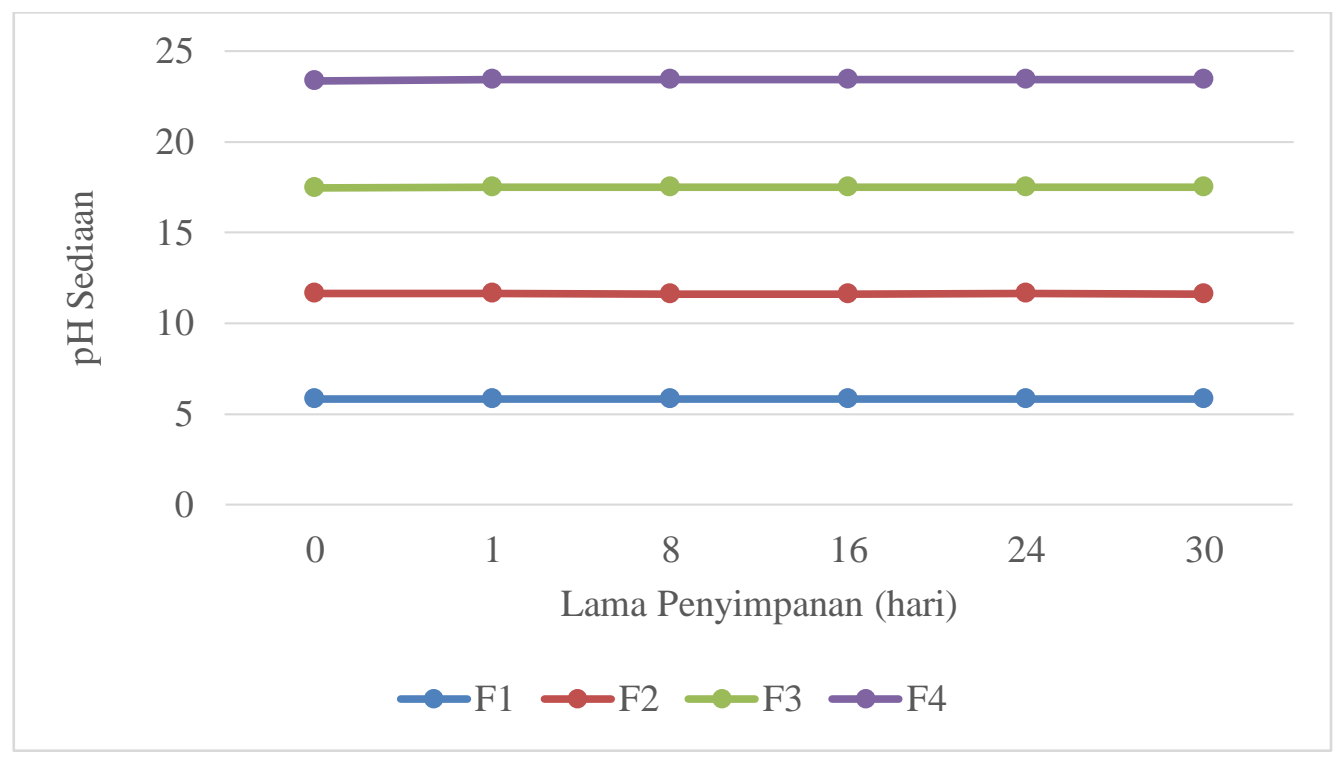

Gambar 3. Hasil pengujian pH sediaan gel selama 30 hari penyimpanan

Pengujian terhadap kemampuan penyebaran sediaan dilakukan sebagai salah satu parameter akseptabilitas sediaan (Martin dkk., 1993). Sediaan akan diminati jika sediaan tersebut mudah diaplikasikan di kulit. Evaluasi terhadap diameter penyebaran sediaan dilakukan untuk mengetahui apakah SPACE-Peptide berpengaruh terhadap kemampuan menyebar sediaan ketika disimpan selama 30 hari. Berdasarkan hasil uji statistika Annova one way pada pengujian kemampuan daya sebar semua 
formula uji didapatkan nilai $p$ value (sig.) lebih besar dari 0,05 sehingga tidak ada perbedaan bermakna antar formula pada diameter sebar sistem gel AMSC-MP selama penyimpanan. Histogram hasil evaluasi diameter sebar sediaan gel freeze dried AMSC-MP selama 30 hari penyimpanan dapat dilihat pada Gambar 4.

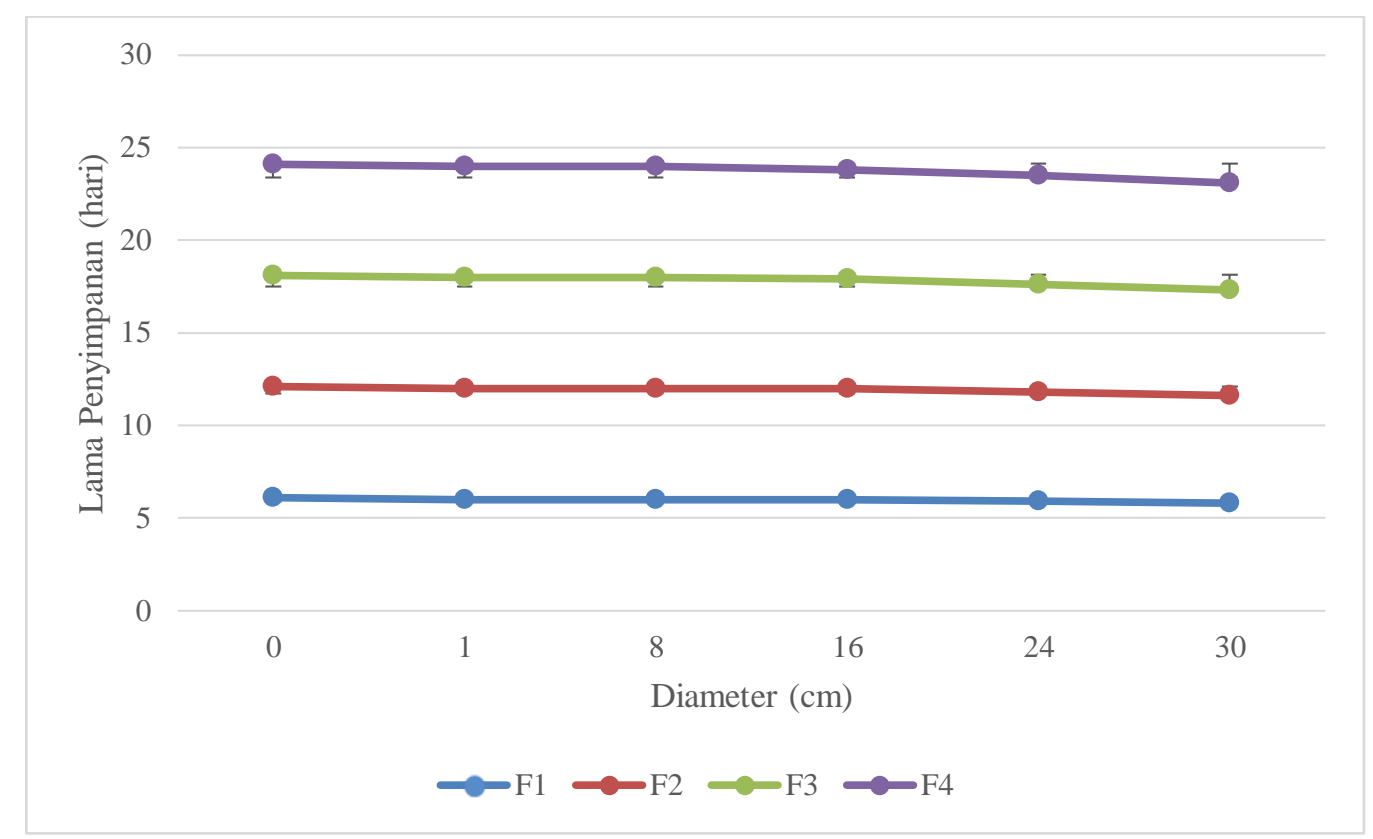

Gambar 4. Grafik hasil pengujian daya sebar pada berat 40 gram selama 30 hari masa penyimpanan

\section{KESIMPULAN}

Dari hasil penelitian diketahui bahwa penambahan SPACE-Peptide tidak mempengaruhi karakteristik fisik (organoleptis, $\mathrm{pH}$, diameter sebar) dari sediaan. Gel yang diperoleh memiliki warna yang jernih (transparan), konsistensi yang kental tekstur yang lembut dan berbau amis. Sediaan gel freeze dried AMSC-MP dengan enhancer SPACE memiliki $\mathrm{pH}$ antara 6,1 dan diameter sebar 6,0 cm sehingga masih berada dalam rentang yang dipersyaratkan. Sediaan cenderung stabil selama masa penyimpanan 30 hari. Penelitian lebih lanjut mengenai efek penambahan SPACE terhadap karakteristik fisik dan stabilitas kimia sediaan dalam waktu yang lebih lama (real time) perlu dilakukan untuk menunjang data stabilitas penggunaan SPACE dalam formulasi sediaan gel freeze dried AMSC-MP.

\section{DAFTAR PUSTAKA}

Barry, B. W. (1983). Dermatological Formulations: Percutaneus Absorption. New York: Marcell Dekker, Inc.

Borelli, A., Anna, L. T., Maria, L. T. \& Franco, M. B. (2018). Cell Penetrating Peptides as Molecullar Carriers for Anti Cancer Agents. Molecules; 23; 2-8.
Chen, Y., Manli, W. \& Liang, F. (2013). Biomaterials as Novel Penetration Enhancers for Transdermal and Dermal Drug Delivery System. Drug Delivery; 20; 199-209.

Ghayah, N., Erawati, T. \& Hendradi, E. (2014). Pengaruh Sistem Tipe Mikroemulsi W/O terhadap Karakteristik. Sediaan dan Pelepasan Natrium Diklofenak (Perbandingan Konsentrasi Surfaktan (Span 80-Tween 80): Kosurfaktan $($ Etanol 96\% $)=6: 1$ dalam Basis Gel HPMC 4000. Jurnal Farmasi dan Ilmu Kefarmasian Indonesia; 1 ; 48-54

Hsu, T. \& Mitragotri, S. (2011). Delivery of SiRNA and Other Macromolecules into Skin and Cells Using a Peptide Enhancer. Proceedings of the National Academy of Sciences of the United States of America; 108; 15816-15821.

Insausti, C. L., Miguel, B., Ana, M., Garcia, F. \& Gregorio, C. (2014). Amniotic Membrane Derived-Stem Cell: Imunomodulatory Properties and Potential Clinical Application. Stem cells and Cloning: Clinical Application; 7; 53-63.

Kumar, S., Michael, Z., Ming, C., Stefano, M., John, A., Muraski \& Samir, M. (2014). Peptides as Skin Penetration Enhancers: Mechanism of 
Action. Journal of Controlled Release; 199; 168-178.

Lund, W. (1994). The Pharmaceutical Codex: Principles and Practice of Pharmaceutics (12th ed). London: The Pharmaceutical Press.

Martin, A., Swarbrick, J. \& Cammarata, A. (1993). Physisical Pharmacy (3rd ed). Philadelphia: Lea and Febiger.

Miki, T. (2011). Amnion Derived Stem Cells: In Quest of Clinical Application. Stem Cell Research and Therapy; 25; 1-11.

Oktaviasari, L. \& Abdul, K. Z. (2017). Formulasi dan Uji Stabilitas Fisik Sediaan Lotion $O / W$ Pati Kentang (Solanum tuberosum) Serta Aktivitasnya Sebagai Tabir Surya. Majalah Farmaseutik; 13; 9-27

Rahmasari, D. (2018). Pengaruh Kadar Surfaktan Kombinasi Tween 80 dan Span 20 terhadap Stabilitas Fisik, Iritabilitas dan Penetrasi
Resveratrol. Tesis; Fakultas Farmasi Universitas Airlangga, Surabaya.

Rosita, C. S. P., Febrina D. P., Nanny H., Irmadita C., Diah, M. I., Dwi, M. \& Fedik, A. R. (2018). The Effects of Amniotic Membrane Stem CellConditioned Medium on Photoaging. Journal of Dermatological Treatment; 30; 478-482.

Rosita, N., Purwanti, T. \& Agustin. (2010). Stabilitas Fisik dan Efektifitas Sediaan Tabir Surya Kombinasi Oksibenson dan Oktil Metoksisinamat dengan Penambahan Asam Glikolat. Majalah Ilmu Kefarmasian; 7; 16-26.

Shoviantari, F. (2017). Efektivitas, Iritabilitas dan Stabilitas Fisik Coenzym Q10 dalam Sistem Penghantaran Nanoemulsi dan Nanostructured Lipid Carriers Sebagai Kosmetika Antiaging. Tesis; Fakultas Farmasi Universitas Airlangga, Surabaya. 